\title{
Origin and depositional model of deep-water lacustrine sandstone deposits in the 7th and 6th members of the Yanchang Formation (Late Triassic), Binchang area, Ordos Basin, China
}

\author{
Xi-Xiang Liu ${ }^{1,2} \cdot$ Xiao-Qi Ding ${ }^{3} \cdot$ Shao-Nan Zhang ${ }^{1,2} \cdot \mathrm{Hao} \mathrm{He}^{4}$
}

Received: 21 June 2016/Published online: 10 January 2017

(c) The Author(s) 2017. This article is published with open access at Springerlink.com

\begin{abstract}
Sandstones attributed to different lacustrine sediment gravity flows are present in the 7 th and 6th members of the Yanchang Formation in the Ordos Basin, China. These differences in their origins led to different sandstone distributions which control the scale and connectivity of oil and gas reservoirs. Numerous cores and outcrops were analysed to understand the origins of these sandstones. The main origin of these sandstones was analysed by statistical methods, and well logging data were used to study their vertical and horizontal distributions. Results show that the sandstones in the study area accumulated via sandy debris flows, turbidity currents and slumping, and sandy debris flows predominate. The sandstone associated with a single event is characteristically small in scale and exhibits poor lateral continuity. However, as a result of multiple events that stacked gravity flow-related sandstones atop one another, sandstones are extensive overall, as illustrated in the cross section and isopach maps. Finally, a depositional model was developed in which sandy debris flows predominated and various other types of small-scale gravity flows occurred
\end{abstract}

Xiao-Qi Ding

xiaoqiding@qq.com

1 State Key Laboratory of Oil and Gas Reservoir Geology and Exploitation, Southwest Petroleum University, Chengdu 610500, Sichuan, China

2 School of Geoscience and Technology, Southwest Petroleum University, Chengdu 610500, Sichuan, China

3 College of Energy, Chengdu University of Technology, Chengdu 610059, Sichuan, China

4 Second Production Plant, PetroChina Changqing Oilfield Company, Qinyang 745000, Gansu, China

Edited by Jie Hao frequently, resulting in extensive deposition of sand bodies across a large area.

Keywords Sediment gravity flows - Sandy debris flows . Binchang area $\cdot$ Yanchang Formation $\cdot$ Ordos Basin

\section{Introduction}

Discussion of the origin of deep-water sandstones began with "Turbidity currents as a cause of graded bedding" (Kuenen and Migliorini 1950). Then, Bouma (1962) proposed the "Bouma sequence", which summarized the vertical sequence of sedimentary structures in turbidites and became the criterion for recognizing turbidites. Based on these criteria, other scholars contributed valuable insights related to this type of deposit and improved turbidity current theory (Yang et al. 2015a). In the same time frame, many depositional models were developed, such as the ancient fan model, the modern submarine fan model and the general fan model (Shanmugam 2000). All these models suggest that turbidity-related sand bodies feature fan-shaped deposits. This consensus has been widely applied in the exploration of deep-water sandstone reservoirs. However, as more deep-water sandstone reservoirs have been discovered, the turbidity current theory has begun to fall short. Shanmugam (1996) noted that high particle concentrations ( $>30 \%$ by volume) lead the support mechanism in the flow change to disperse pressure and viscosity of clay minerals which essentially represent the physical properties of the sandy debris flow. Other scholars noted that sandy debris flows tend to be deposited in the form of lumps, which modelled as interrupted sand bodies (Shanmugam and Moiola 1997) and tongue-like sand bodies (Zou et al. 2012). Distribution patterns of these 
deposits are entirely different from those of turbidites. Recently, scholars described a special type of turbidity current called hyperpycnal flow (Mulder et al. 2003; Zavala et al. 2011). Unlike turbidity currents, hyperpycnal flow is of significantly long duration because it is caused by seasonal floods, snow-melt floods and melting glaciers (Huneke and Mulder 2011). Therefore, the resulting sandstones are interrupted less than those related to waning turbidity currents or sandy debris flows and show gradational changes in the vertical and the horizontal direction (Zavala and Arcuri 2016).

The above analyses suggest that reservoir characteristics such as the sand distribution pattern, scale and continuity of these various deep-water sandstones differ significantly because of variations in transport and depositional models. The 7th and 6th members of the Yanchang Formation in the Binchang area of the Ordos Basin were deposited in a deep-water environment (Lei et al. 2015) and are the main production formation of tight oil in China (Yang et al. 2012; Ding et al. 2013; Yuan et al. 2015). Understanding the origin, distribution pattern, scale and continuity of this sandstone is important, and these factors must be considered during exploration and decision-making in the development of the oil field.

This paper aims to discuss the main origin of sand bodies by summarizing the sedimentary characteristics observed in cores and outcrops and then to determine the scale and distribution pattern based on well logging information. Finally, it aims to construct a depositional model for these deep-water lacustrine sandstones and provide a reference for further exploration and development of this area.

\section{Geological background}

The Ordos Basin is a multi-episodic cratonic basin in central China that covers an area of $370,000 \mathrm{~km}^{2}$. The basin is bordered by the Yin Mountain on the north, the Liupan Mountain on the west, the Lüliang Mountain to the east and the Qin Mountain on the south. The study area is located around Xunyi and Binxian, near the Weibei uplift, on the southern Yi-Shan slope in the Ordos Basin (Fig. 1ac). The basement of the Ordos Basin is Archaeozoic and lower Proterozoic metamorphic rocks. The basin has accumulated sediments since the Mesoproterozoic, resulting in a sediment column that is $5,000-10,000 \mathrm{~m}$ thick. The sedimentary rocks in the basin that predate the Permian were deposited under marine conditions (He 2003). By the middle Permian to Late Triassic, the northern China Plate and Yangtze Plate began to collide and merge (Deng et al. 2013; Yang and Deng 2013). This collision caused the Qin Mountains to be uplifted and the residual marine basin to close. The collision also resulted in southward migration of the basin centre and steepened the bottom topography in the southern portion of the basin. By the Late Triassic, when deposition of the Yanchang Formation began, the basin was a deltaic-lacustrine depositional system (Fig. 1b) with a 900-1600-m-thick set of clastic rocks that recorded a complete cycle of lacustrine basin initiation, development and cessation (Fu et al. 2013; Liu et al. 2015a). The formation can be divided into 10 members (Fig. 2). Member 10 was deposited during the initial creation of the lake. Members 9 and 8 were deposited during an episode of major transgression. Member 7 was deposited during an episode of accelerated subsidence, when the water depth increased from 50 to $120 \mathrm{~m}$, causing significant lake expansion. Laterally extensive black shale was deposited during this time (Lei et al. 2015). Deep-water sandstones of Member 7 were deposited on top of the black shale. The lake began to shrink during the deposition of Member 6. Members 5-1 were deposited during a period of major lake contraction, after which the lake gradually disappeared. Adequate coring data from the Yanchang Formation and outcrops around the study area make it an ideal place to study the origin of deep-water lacustrine sandstones.

\section{Origin analysis of deep-water sandstones}

\subsection{Facies and interpretation}

Based on the observation of 42 cored wells and outcrops near the study area, 7 typical facies were identified according to their lithologies and sedimentary characteristics (Table 1).

\subsubsection{Facies $A$}

Facies A is composed of black-dark grey mudstone and shale. Silty laminaes are ubiquitous in the mudstone (Fig. 3a). The thickness of the mudstone (or shale) layer reaches $40 \mathrm{~m}$ in the study area.

The thick black mudstone reflects a reducing and weak hydrodynamic condition in the deposition area. This facies, therefore, represents a deep-water environment.

\subsubsection{Facies $B$}

Facies B is composed of light to dark grey fine-grained sandstone with an individual bed thickness ranging from 2 to $3 \mathrm{~m}$. No significant grading is observed. Abrupt contacts with mudstones are present at both the bottom and top surface of sandstones. Most of the top contact surfaces are irregular (Fig. 3b). Dark muddy clasts are ubiquitous and 


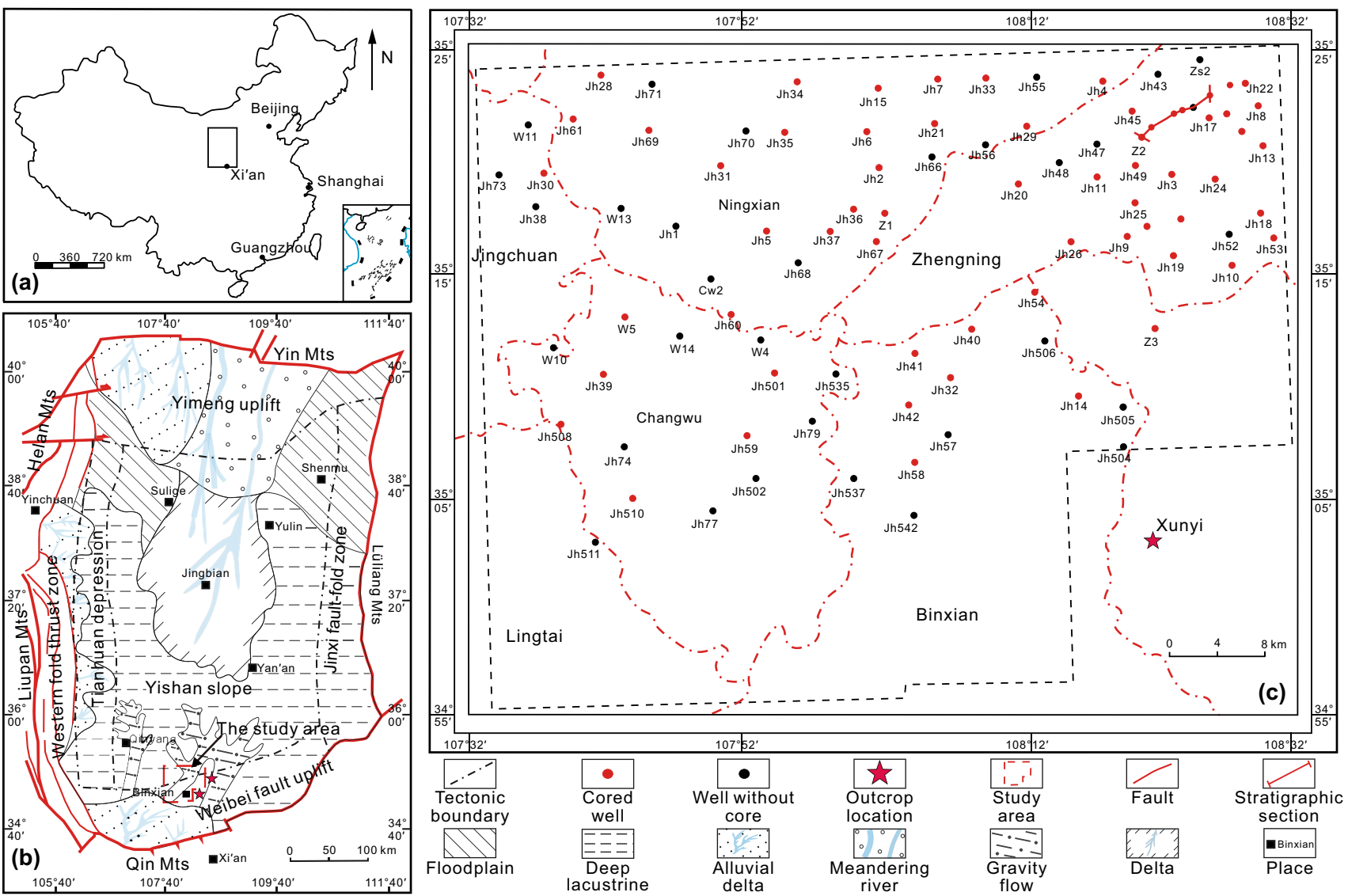

Fig. 1 Geologic setting and well distribution of the study area. a Map showing the Ordos Basin in central China; b sketch map of the Ordos Basin showing the location of the study area and the lithofacies palaeo-geographic map of the 7th member of the Yanchang Formation; and c detailed map showing the study area, wells and outcrops

usually exhibit a planar fabric (Fig. 3c). Yellow muddy clasts are also present, some of which are coated with black mudstone (Fig. 3d). Unlike clasts commonly found at the bottom of a layer in a fluvial environment, these clasts are primarily found in the middle or upper parts of sandstones.

The presence of clasts in the middle or upper parts of sandstones indicates the viscosity and density of the transporting fluid, which was able to support mudstone clasts and allow grains to deposit via freezing en masse and without grading. This is typical of sediments transported by plastic sandy debris flows (Zou et al. 2012; Shanmugam 2013; Xian et al. 2013). The planar fabric of the clasts further supports the hypothesis that the sediment was transported by plastic flows (Talling et al. 2012a; Yang et al. 2014). The presence of mudstone coats can be attributed to muddy slurry adhering to the clasts as they were rolled or spun by the shear stresses along their upper and lower surfaces ( $\mathrm{Li}$ et al. 2014, 2016). These features also indicate that the deposits did not result from a turbidity current (with water between grains). Therefore, it can be concluded that this facies is the product of sandy debris flow deposition.

\subsubsection{Facies $C$}

Facies $\mathrm{C}$ is composed of light grey sandstone lacking grading, sedimentary structures or muddy clasts. The bottom and top of the sandstone are typically abrupt contacts with mudstones. However, the bottom contact surfaces are very smooth and the top contact surfaces are rough and irregular (Fig. 4). In outcrops, this facies displays abrupt lateral terminations with tongue-like shapes (Fig. 5a).

Massive sandstones such as these could have been deposited by grain flow, sandy debris flow or hyperpycnal flow (Bagnold 1956; Zavala 2006; Li et al. 2011a; Gao et al. 2012). Hampton (1975) concluded, based on experimentation, that a clay content of less than $2 \%$ is required for the development of grain flow. However, the thin section observation and X-ray diffraction analysis show that the average clay content in these sandstones is as high as $8.6 \%$, which suggests that these sandstones did not form via grain flow. Hyperpycnal flow, however, is quasi-steady flow that produces sand bodies with good lateral continuity from the source to the depositional district (Tan et al. 2015; Yang et al. 2015b). However, 


\begin{tabular}{|c|c|c|c|c|c|c|}
\hline Series & Formation & Member & $\begin{array}{c}\text { Thickness } \\
\text { (m) }\end{array}$ & Submember & Lithology & $\begin{array}{l}\text { Depositional } \\
\text { environment }\end{array}$ \\
\hline \multicolumn{7}{|c|}{ Quaternary } \\
\hline Lower Cretaceous & \multicolumn{2}{|c|}{ Zhidan } & $0-1200$ & & & Eolian and alluvial \\
\hline Upper Jurassic & \multicolumn{2}{|c|}{ Anding } & $0-340$ & & & Lacustrine \\
\hline \multirow{2}{*}{ Middle Jurassic } & \multicolumn{2}{|c|}{ Zhiluo } & $0-600$ & & בע & Fluvial \\
\hline & \multicolumn{2}{|c|}{ Yanan } & $0-300$ & & ב" & Fluvial-lacustrine \\
\hline Lower Jurassic & \multicolumn{2}{|c|}{ Fuxian } & $0-156$ & & & Fluvial \\
\hline \multirow{13}{*}{ Upper Triassic } & \multirow{13}{*}{ Yanchang } & Chang $_{1}$ & $0-240$ & $\begin{array}{l}\text { Chang }_{1}{ }^{1} \\
\text { Chang }_{1}{ }^{2} \\
\text { Chang }_{1}{ }^{3}\end{array}$ & \multirow{2}{*}{ 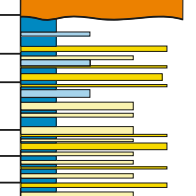 } & $\begin{array}{c}\text { Swamp and } \\
\text { shallow lacustrine }\end{array}$ \\
\hline & & \multirow{2}{*}{ Chang $_{2}$} & \multirow{2}{*}{$120-150$} & $\begin{array}{l}\text { Chang }_{2}{ }^{2} \\
\text { Chang }_{2}{ }^{2} \\
\end{array}$ & & \multirow{3}{*}{ Fluvial and delta } \\
\hline & & & & Chang $_{2}{ }^{3}$ & "l & \\
\hline & & Chang $_{3}$ & $90-110$ & $\begin{array}{l}\text { Chang }_{3}{ }^{1} \\
\text { Chang }_{3}{ }^{2} \\
\text { Chang }_{3}{ }^{3} \\
\end{array}$ & 㢳 & \\
\hline & & \multirow{2}{*}{ Chang $_{4+5}$} & \multirow{2}{*}{$80-100$} & Chang $_{4+5}{ }^{2}$ & 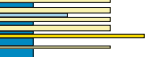 & \multirow{2}{*}{ Shallow lacustrine } \\
\hline & & & & Chang $_{4+5}{ }^{1}$ & 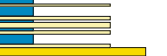 & \\
\hline & & Chang $_{6}$ & $110-130$ & $\begin{array}{l}\text { Chang }_{6}{ }^{1} \\
\text { Chang }_{6}{ }^{2} \\
\text { Chang }_{6}{ }^{3} \\
\end{array}$ & ए” & $\begin{array}{c}\text { Delta and } \\
\text { shallow lacustrine }\end{array}$ \\
\hline & & Chang $_{7}$ & $100-120$ & $\begin{array}{l}\text { Chang }_{7}^{1} \\
\text { Chang }_{7}^{2} \\
\text { Chang }_{7}{ }^{3}\end{array}$ & 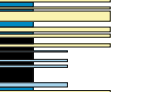 & $\begin{array}{c}\text { Delta and } \\
\text { deep lacustrine }\end{array}$ \\
\hline & & Chang $_{8}$ & $75-90$ & $\frac{\text { Chang }_{8}{ }^{1}}{\text { Chang }_{8}{ }^{2}}$ & 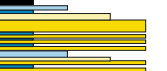 & \multirow{2}{*}{$\begin{array}{c}\text { Delta and } \\
\text { shallow lacustrine }\end{array}$} \\
\hline & & Chang $_{9}$ & $80-110$ & $\begin{array}{l}\text { Chang }_{9}{ }^{1} \\
\text { Chang }_{9}{ }^{2}\end{array}$ & 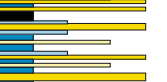 & \\
\hline & & \multirow{3}{*}{ Chang $_{10}$} & \multirow{3}{*}{$240-280$} & Chang $_{10}{ }^{1}$ & 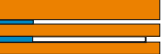 & \multirow{3}{*}{ Fluvial } \\
\hline & & & & Chang $_{10^{2}}$ & 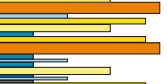 & \\
\hline & & & & Chang $_{10^{3}}$ & 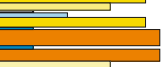 & \\
\hline
\end{tabular}

Fig. 2 Stratigraphic column showing the Mesozoic stratigraphy, lithology and depositional environments in the study area, southern part of the Ordos Basin, central China

the sand bodies in the study area are generally characterized by small scales and poor continuity (see chapter 4.2). Hyperpycnal flows significantly erode the underlying layer, but sandstones observed in cores and outcrops in the study area display typically smooth contacts with underlying layers. Smooth bottom contacts are more likely produced by hydroplaning associated with sandy debris flows (Marr et al. 2001). The abrupt termination of sandstones and the irregular contact surfaces with overlying layers also indicate that the sediment was deposited by the freezing en masse of a plastic sandy debris flow (Talling et al. 2012b; Shanmugam 2016). Therefore, these massive sandstones are more likely the result of sandy debris flow deposition. 
Table 1 Characteristics of different facies in the study area

Facies Lithology and sedimentary structure

A Black-dark grey mudstone or shale. Silty laminae are ubiquitous

B Light to dark grey fine grained sandstones. Dark muddy clasts are ubiquitous and exhibit a planar fabric. Mud-coated clasts can be observed

C Light grey massive sandstones. Their bottom and top often are in abrupt contact with mudstones. The bottom contact surface usually very smooth and the top contact surface rough and irregular

D Grey fine-to-silt sandstone with small scale parallel bedding or cross bedding. Weak normal grading can be observed

E Light grey fine-to-silt sandstones or mudstones with lenticular, flaser or wavy bedding and normal grading can be observed. Their bottom often has abrupt contact with mudstones

F Grey sandstones with deformation structures, such as glide planes, steep fabric and slump folds

G Black mudstone or silty mudstone that is mainly characterized by steeply dipping mud layers (steep fabric) and sandstone injection
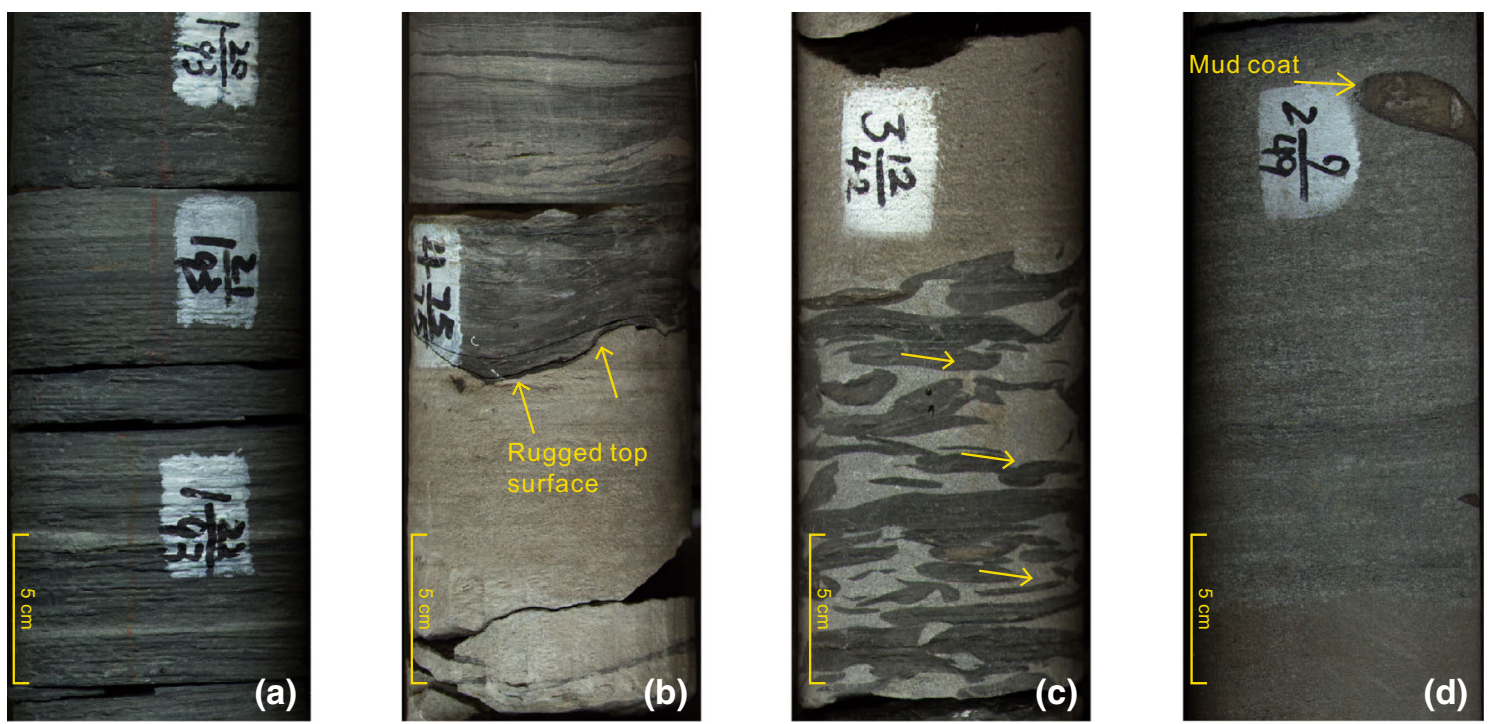

Fig. 3 Photographs of sedimentary structures in facies A and facies B. a Black mudstone with silty laminae, well Jh4, 1319.57-1319.81 m. b Sandstone with irregular abrupt top contact surface, well Jh4, 1370.89-1371.23 m. c Mud clasts with planar fabric, well Jh9, 937.9-938.14 m. d Yellow mud clast with a black mud coat, well Jh2, 1317.11-1317.35 m
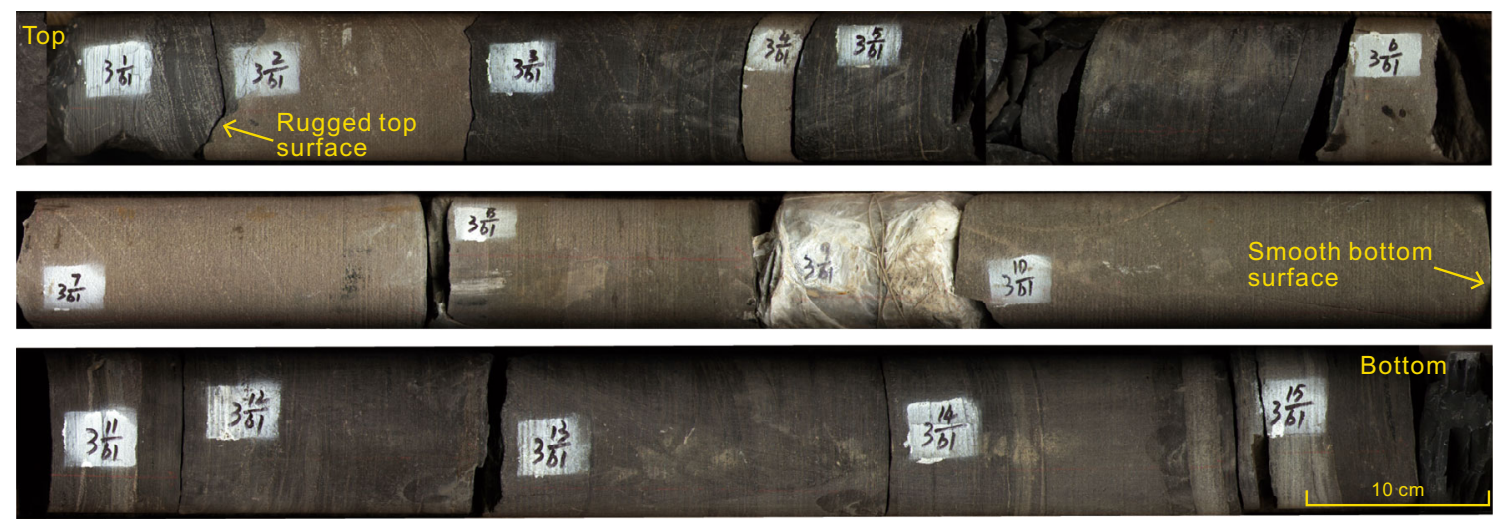

Fig. 4 Photographs of facies $\mathrm{C}$ showing massive sandstone with an irregular top surface and a smooth bottom surface, well Jh25, $1277.51-1280.10 \mathrm{~m}$ 


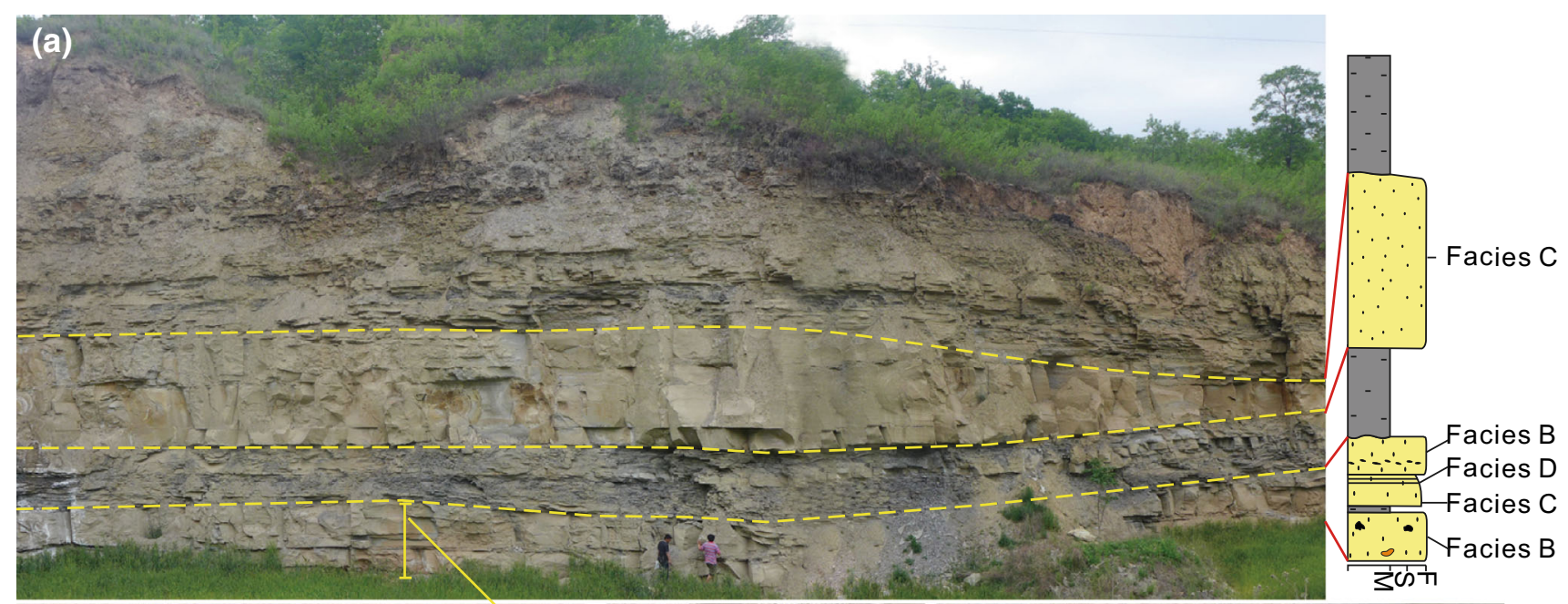

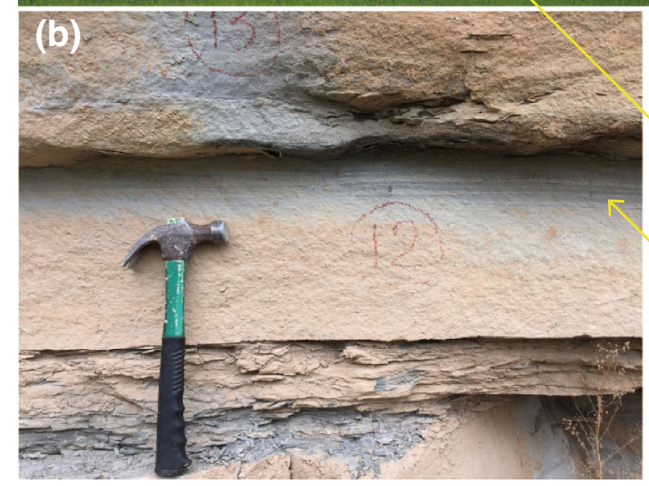

.... Mud clasts with planar fabric

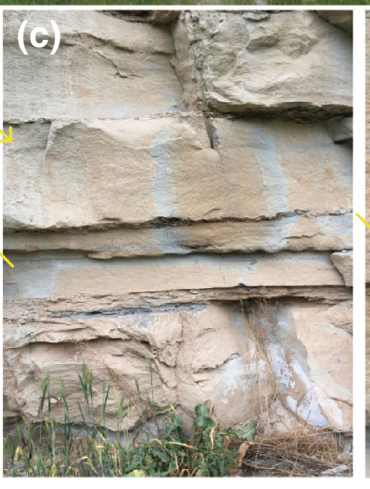

$\equiv$ Parallel bedding

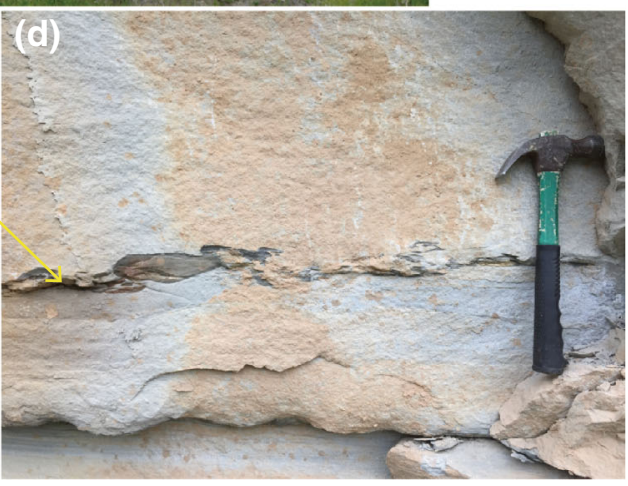

$\because \because$ Mud clast

Fig. 5 Photographs of an outcrop of the Chang 7 member. a Upper sandstone, facies C, featuring an abrupt termination with a tongue-like shape. b Photograph of facies D. c Detailed photograph of the lower sandstone showing a typical vertical assemblage of facies B, C and D. d Planar fabric, which is ubiquitous in facies B

\subsubsection{Facies $D$}

Facies D is composed of grey fine to silty sandstone with parallel bedding and small-scale cross-bedding. Weak normal grading can be observed. The thickness of facies D is no more than $10 \mathrm{~cm}$. It typically overlies facies $\mathrm{B}$ or facies C (Fig. 5b-d).

The parallel bedding or cross-bedding is related to the traction process. However, the scale of the traction structure is small which reflects the weak hydrodynamic condition and a small impact area. Additionally, normal grading usually indicates that this facies is associated with turbidity currents (Mulder and Alexander 2001). Therefore, we conclude that as a debris flow advanced through the water, shear stress generated along the upper boundary of the water-slurry interface. Then, the shear stress leads to erosion and entrainment of sediment from the surface of the debris flow into the clear water above (Marr et al. 2001). The entrainment of sediment into the overriding clear water resulted in the formation of a dilute subsidiary turbidity current and a traction ability in the surrounding water. Thus, this facies with weak normal grading and small traction structure is generally observed above facies $\mathrm{B}$ and facies $\mathrm{C}$ and could be a criterion for identify sandy debris flow of different stages. This phenomenon has been observed by other scholars (Yang et al. 2014; Liu et al. 2015b).

\subsubsection{Facies $E$}

Facies $\mathrm{E}$ is composed of light grey fine to silty sandstone or mudstone with lenticular (Fig. 6a), flaser (Fig. 6b) or wavy bedding (Fig. 6c). Most of the sand beds are no more than $1 \mathrm{~m}$ thick. A transition from flaser bedding at the bottom to lenticular bedding at the top can be observed where the sand body is thick enough. Normal grading can also be observed, and the bottom of the sandstone has abrupt contacts with mudstone (Fig. 6).

The wavy, flaser and lenticular bedding are all related to traction processes (Mulder and Alexander 2001), and the 


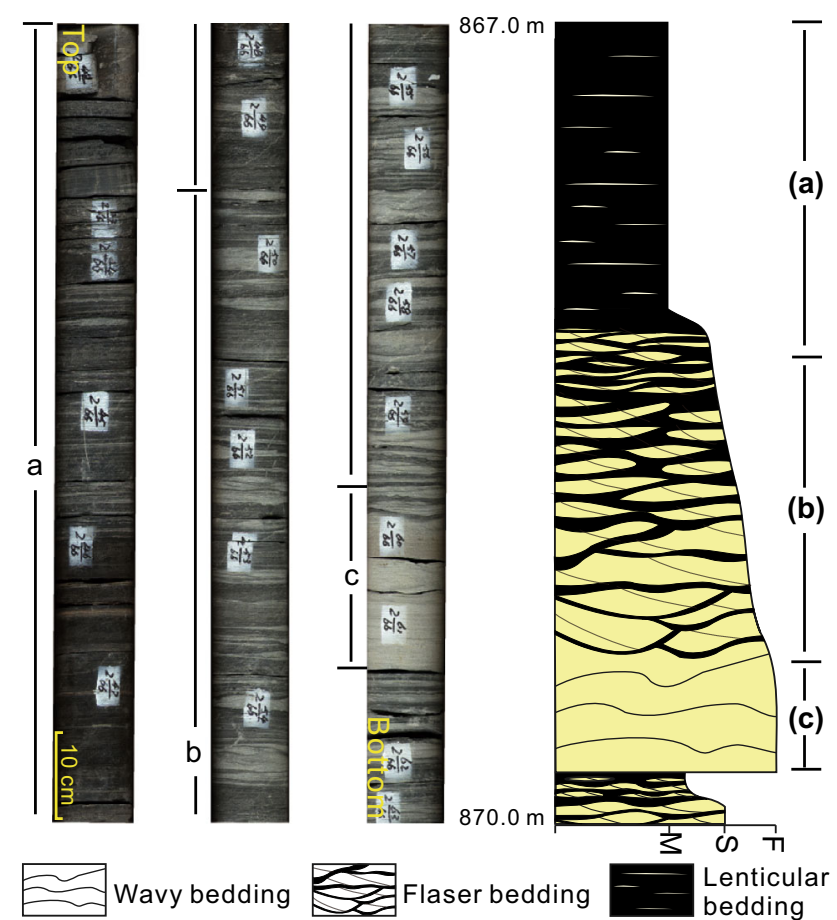

Fig. 6 Photographs of facies E showing normal grading and different kinds of bedding. a Mudstone with lenticular bedding. b Silty to fine sandstone with flaser bedding and an upward-increasing mud content. c Fine sandstone with wavy bedding. Jh9, 867-870 m

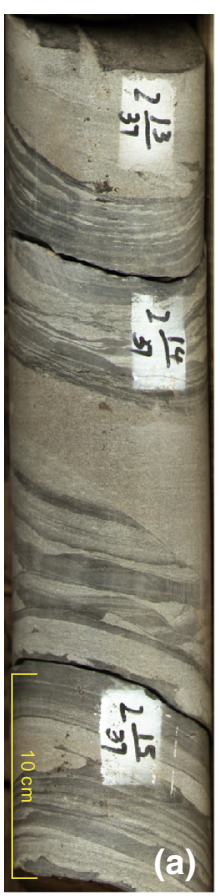

$\approx$ Glide plane
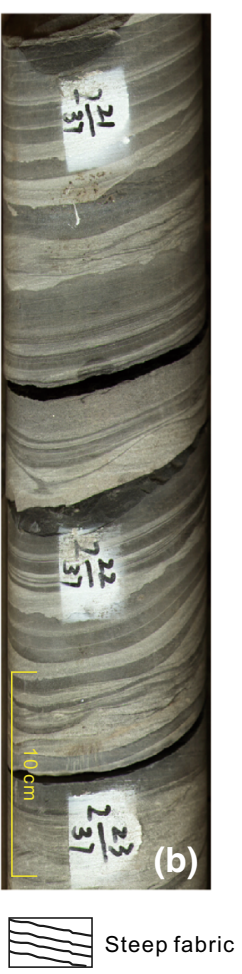

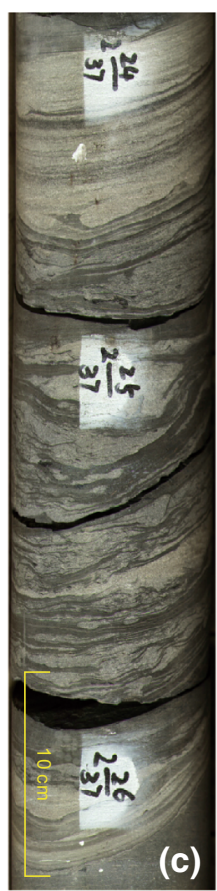

Sand injection
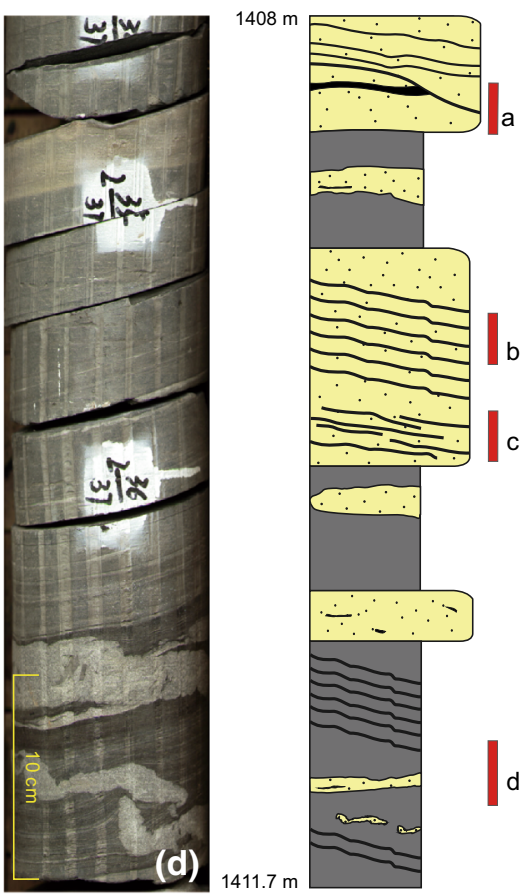

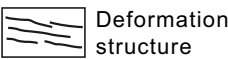

(a)

(b)

\section{(c)} , , 

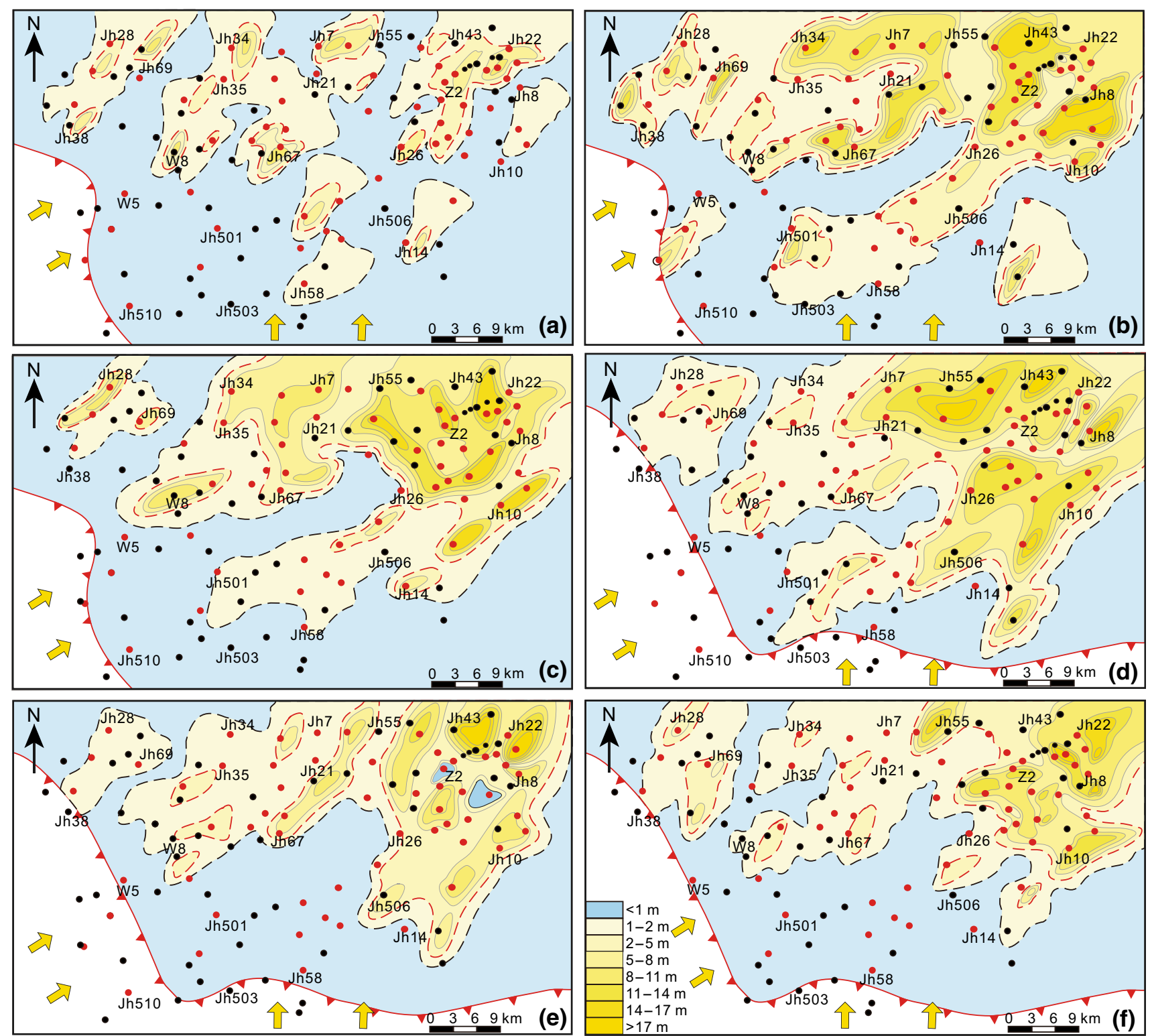

Stratigraphic
distinction line

Sandy debris flon

distinction line _._ sediment area _ _ sediment area

Fig. 8 Isopach maps of sandstone thicknesses; note that abrupt thickness variations and the thick sandstones are generally distributed in the northeast portion of the study area. a Isopach map of the Chang ${ }_{7}^{3}$ submember. b Isopach map of the Chang $\mathbf{g}_{7}^{2}$ submember. $\mathbf{c}$ Isopach map of the Chang $_{7}^{1}$ submember. d Isopach map of the Chang ${ }_{6}^{3}$ submember. e Isopach map of the Chang ${ }_{6}^{2}$ submember. f Isopach map of the Chang $_{6}^{1}$ submember

normal grading suggests that the sediments were deposited by waning turbidity currents that deposited coarse-grained material first followed by fine-grained material ( $\mathrm{Li}$ et al. 2011b, c; Pu et al. 2014). However, as in facies D, these beds are thin, which indicates that the energy of the currents was low. Therefore, we conclude that the deposits may have been formed by subsidiary turbidity currents transformed from sandy debris flows.

\subsubsection{Facies $F$}

Facies $\mathrm{F}$ is composed of grey sandstone with deformation structures such as glide planes (Fig. 7a), steep fabric (Fig. 7b) and slump folds (Fig. 7c). The bottoms and tops are typically abrupt contacts with mudstones, which also display deformation structures (Fig. 7). The deformed layers could reach $4 \mathrm{~m}$ in thickness. 
Table 2 Characteristics of sandstones of various origins in the Binchang area, Ordos Basin, China

\begin{tabular}{llll}
\hline Origin & Slumping & Sandy debris flow & Turbidity current \\
\hline Lithology & Silty fine-grained sandstone or mudstone & Silty fine-grained sandstone & Mainly silty sandstone \\
Colour & Light greyish-black & Light grey & Light to dark grey \\
Sedimentary structure & Glide planes & Mud clasts with planar fabric & Wavy bedding \\
& Steep fabric & Irregular upper contacts & Flaser bedding \\
& Slump folds & & Lenticular bedding \\
Grading & No distinct grading & No distinct grading & Normal grading \\
Facies & Facies F & Facies B & Facies D \\
& Facies G & Facies C & Facies E \\
Bed geometry & - & Tongue-shaped & Fan-shaped \\
\hline
\end{tabular}

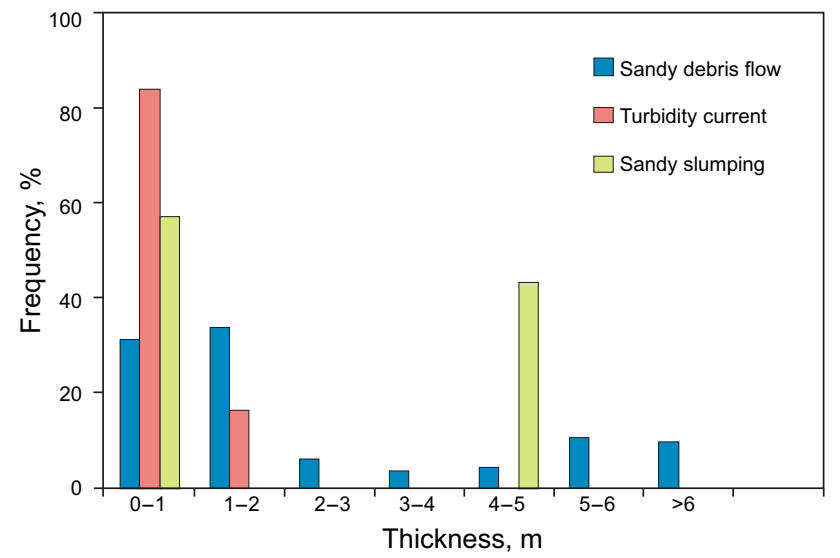

Fig. 9 Thicknesses of sandstone bodies of various origins

The slump folding suggests that the sediment experienced soft-sediment deformation. The glide plane is a dislocation in the sedimentary structure or bedding, which suggest internal soft-sediment deformation. The steep fabric reflects that the sandstone experienced slumping (Herrington et al. 1991). Thus, this facies is attributed to synsedimentary sand slumping.

\subsubsection{Facies $G$}

Facies $\mathrm{G}$ is composed of black mudstone and light grey silty mudstone that is characterized primarily by steeply dipping mud layers (steep fabric) and sandstone injection (Fig. 7d). This facies is usually adjacent to facies $\mathrm{F}$ (Fig. 7).

The black mudstone indicates deposition in a deep-water environment. In this environment, the steeply dipping mud layers can only be attributed to mud slumping. The injected sand is also related to loading induced by slumping (Shanmugam 2012). This facies is therefore the product of slumping.

\subsection{Spatial distribution of sandstones}

The sedimentary facies control the distribution of the sand bodies, and the origin of the sandstones can be deduced from the geometry of the sandstone beds. Based on the analysis of logging data in cored wells, a logging identification standard has been established. With the identification standard, sand bodies with a thickness of at least $1 \mathrm{~m}$ were distinguished. Then, sand-thickness contour maps of the various submembers were prepared.

The isopach map illustrates the localized thickening and thinning that is common in these beds. Sand bodies thicker than $5 \mathrm{~m}$ exist in the form of lumps and display rapid lateral thickness change (Fig. 8). Amy et al. (2005) noted that this horizontal distribution of sand bodies is a typical characteristic of sandy debris flows. Moreover, the thick sand bodies distributed primarily in the north-eastern part of the study area, far from the sedimentary sources. This suggests that the sandstone may not have been transported by waning traction flows whose sediment thickness decreases with the transporting distance (Shanmugam 2012).

\subsection{Origins of deep-water sandstones}

From the above analyses, black mudstones (shales) are widely distributed, and the coarsest grains in the 7th and 6th members of the Yanchang Formation are fine sand, which indicate weak hydrodynamic conditions. The rocks lack large-scale bedding, indicating weak traction processes. The lateral continuity of the sandstone bodies is poor, which suggests that the sand was not transported by flows of long duration. The thick sandstone beds display abundant characteristics of plastic flow transport such as massive sandstones (facies B), mud clasts with planar fabrics, irregular upper contacts and mud coatings. Additionally, previous investigators noted that during the 
deposition of the Yanchang Formation, strong tectonic movements such as earthquakes and volcanic eruptions occurred frequently; these events could trigger gravity flows (Deng et al. 2013; Zhang et al. 2014). Thus, we conclude that the deep-water sandstones of the 7th and 6th members of the Yanchang Formation are the product of sediment gravity flows including sandy debris flows, subsidiary turbidity currents and sandy slumping (Table 2).

\section{Discussion}

\subsection{The main origin of deep-water sandstone}

Based on the above-mentioned standard, the facies of the deposits in the study area were identified by observing $715.3 \mathrm{~m}$ of cores collected from 42 cored wells. In total, the black mudstones are $273.1 \mathrm{~m}$, sandstones attributed to sandy debris flows are $354.5 \mathrm{~m}$, turbidite sandstones are $65 \mathrm{~m}$, and the sandstones attributed to sand slumping are $22.7 \mathrm{~m}$. In terms of thickness, the 6th and 7 th members of the Yanchang Formation are dominated by sandy debris flow sandstones followed by turbidite sandstones. The slump sand bodies are present in only a few wells.

A statistical analysis of the thicknesses of single-event sand bodies attributed to sandy debris flows shows that the layers are generally less than $2 \mathrm{~m}$ thick (Fig. 9, blue bars).
However, some thick sandstone bodies of this type are developed in local areas.

The total thickness of the turbidite sandstones is small, and most of the single-event sand bodies of this type are less than $1 \mathrm{~m}$ thick (Fig. 9, brown bars), which suggests that the scale of turbidity currents in the study area was small. Thus, turbidity currents were not the main origin of the deep-water sandstone in the study area.

Some thick sand bodies can be attributed to slumping (Fig. 9, green bars). However, the total thickness of this type of sandstone is small, and this type is observed in only a few wells. Overall, this type of sand body is not abundant in the study area.

Therefore, the thick sand bodies in the study area were deposited primarily by sandy debris flows. The sand bodies attributed to turbidity currents come second, and the slumping-related sandstone bodies are present only in local areas.

\subsection{Scale of deep-water sandstones}

A cross section through 6 wells, with an average well spacing of approximately $1 \mathrm{~km}$, was made (Fig. 10) to further investigate the scale of the sand bodies in the study area. Based on the lateral distribution characteristics of the sand bodies in the cross section, the sand bodies in study area are suggested to have the following features:

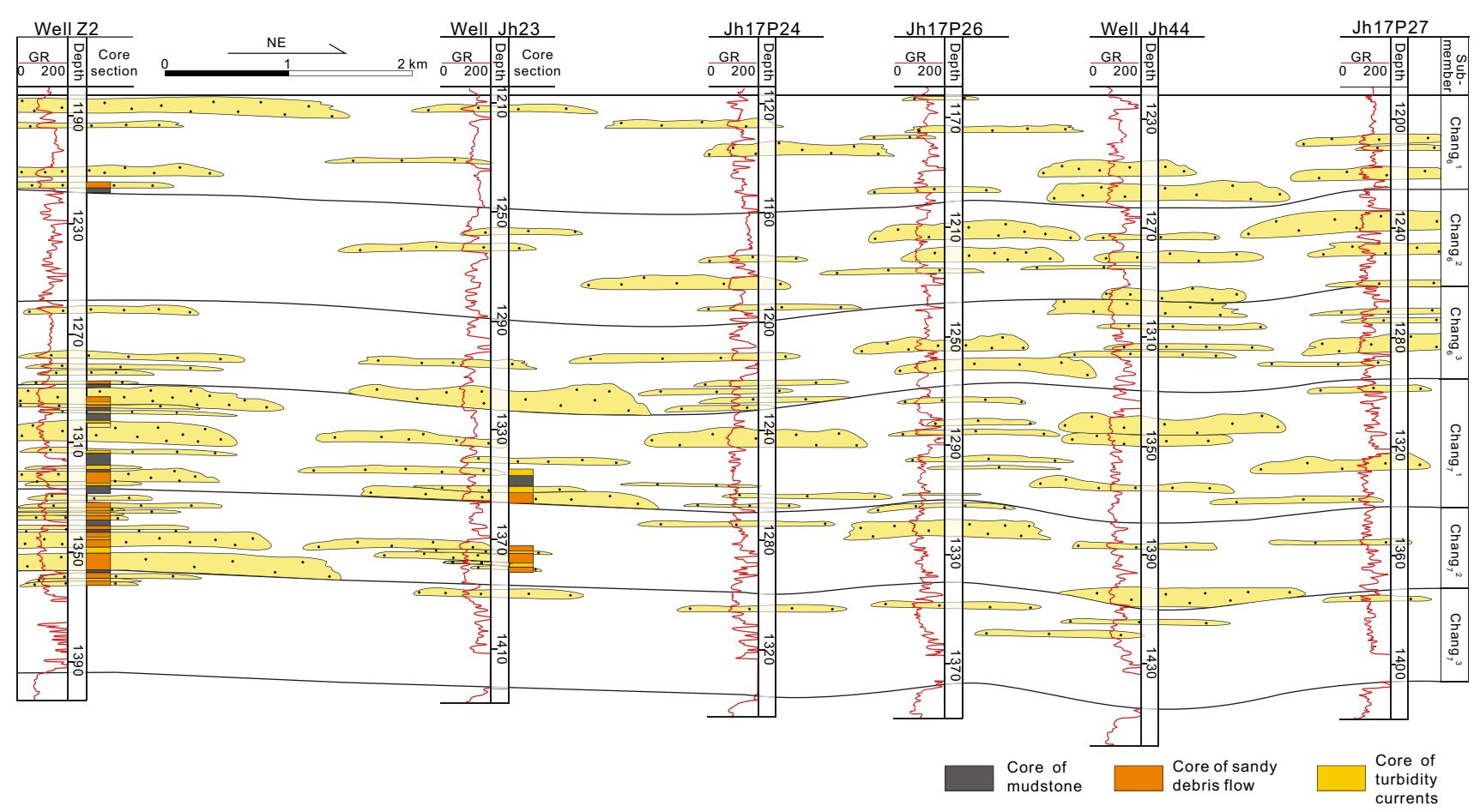

Fig. 10 Cross section of Chang 7 and Chang 6 members. See Fig. 1c for the location of the section 


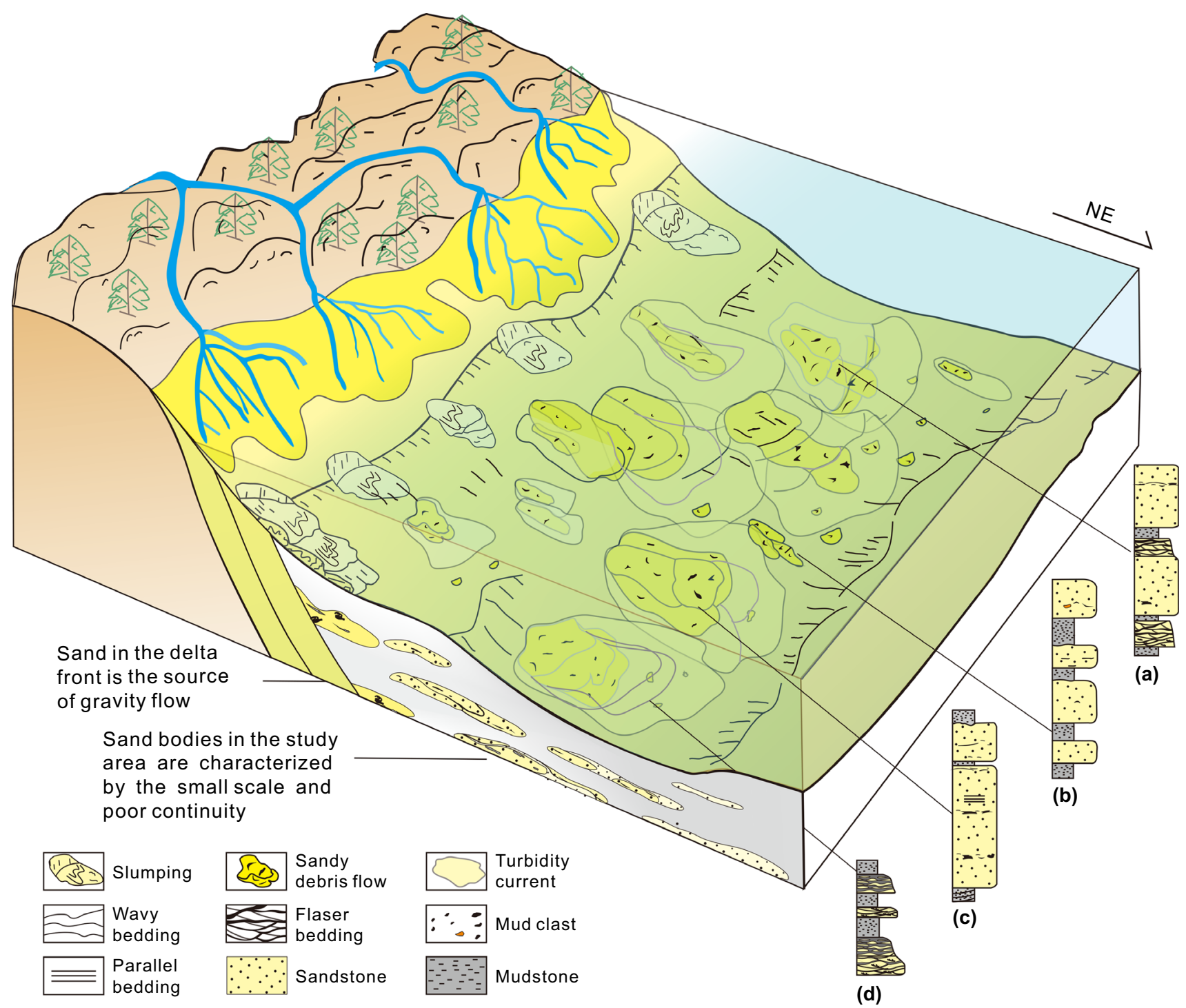

Fig. 11 Depositional model of sediment gravity flows in the 6th and 7th members of the Yanchang Formation in the Binchang area, Ordos Basin, China. a Interbedded sandy debris flows and turbidity currents; $\mathbf{b}$ interbedded sandy debris flows and mudstones; $\mathbf{c}$ stacking of multiple sandy debris flows; and $\mathbf{d}$ interbedded turbidity currents and mudstones

(1) The scale of single-event sand bodies is small, and individual sand bodies are usually less than $2 \mathrm{~km}$ in size.

(2) The single-event sandstone bodies are thin, although the frequency of gravity flow deposition resulted in a large cumulative thickness.

(3) The frequency of gravity flow events varied significantly from one neighbouring well to the next, and thick sandstones are developed only in small area.

The above features can be observed directly in the outcrops. One particular outcrop in the study area exhibits two sets of sandy debris flow sandstones at the top and bottom (Fig. 5). The sand bodies at the top are approximately $6 \mathrm{~m}$ thick but pinch out laterally within $15 \mathrm{~m}$
(Fig. 5a). The sand bodies at the bottom are only $2 \mathrm{~m}$ thick but display parallel bedding and planar fabric (Fig. 5b-d), which indicates that the sand bodies are the result of two stages of sandy debris flows. All the above evidence adequately supports the conclusion that the sand bodies in the study area are characterized by small individual events that rapidly thin out laterally, which leads to poor continuity. However, a large cumulative thickness resulted from the stacking of multiple gravity flow deposits.

\subsection{Sedimentary models}

Based on the above analysis, a sedimentary model of the deep-water sandstones in the Binchang area was developed 
(Fig. 11). A significant number of deposits in the study area were re-mobilized by sediment gravity flow and re-transported from a gently sloping front delta area to the adjacent lake plain due to an earthquake disturbance or the naturally unstable nature of the delta front area (i.e. sand deposited on water-bearing muddy deposits) (Zhang et al. 2014). Thus, the sand in the delta front area is the source of the deep-water sandstones. Re-transportation occurred mainly in the form of sandy debris flows and turbidity currents. Due to the short travel distance of the slumping-related sand (Shanmugam 2012), these deposits are believed to be present near the delta front zone, outside the study area.

The thick sand bodies in the study area are generally present in the form of lumps. These thick sand bodies, in most cases, resulted from the stacking of sediment gravity flows, in the form of stacking and interfingering of multiple sandy debris flows and turbidity currents (Fig. 11a-c). The individual subsidiary turbidity current deposits are thin but extensively distributed around the thick sand bodies (Fig. 11d). According to the drilling situation and previous research, the thick layers of sand are generally located far from the material source areas where palaeo-water depths were greater (Fu et al. 2013). This distribution is due to the nature of sandy debris flows, which, under the influence of gravity, are likely to move into deeper water where the gravitational potential energy is lower.

\section{Conclusions}

1. Three different types of sandstone were identified in the study area. The massive sandstone (facies C) and the sandstone containing muddy clasts and "mud coatings" (facies B) are the products of sandy debris flows. Facies D and facies E, which display traction structures and normal grading, represent deposition by turbidity currents. These deposits are thin, which indicates that the energy of the turbidity currents was low. Therefore, the deposits are interpreted as being the products of subsidiary turbidity currents generated by sandy debris flows. Facies $F$ and $G$, which are characterized by soft-sediment deformation, are the product of sand slumping.

2. The sandstones in the study area were deposited mainly by sandy debris flows. This type of sandstone is characterized by small-scale single events, rapid lateral pinch outs and multi-stage development. The turbidite sandstones are widespread, but the scale of beds represented by single events was too small to form thick sandstones.

3. A depositional model was developed in which sandy debris flows predominated, turbidity currents were secondary and sandy slumping was localized. In this model, the sandstones developed far from their source at substantial palaeo-water depths. The thick sandstones resulted from the accumulation of multiple gravity flow deposits, which led to lump plan-form geometry. The turbidites generally overlie the sandy debris flow deposits or are interbedded with mudstone near the sandy debris flow deposits. And lumpingrelated sandstone bodies are present only in local areas.

Acknowledgements This work was supported by the Science Foundation Programs (41302115). We are grateful to two reviewers who provided useful comments to help improve the manuscript and the senior engineer He Pumin, North China Company of SINOPEC, who assisted in the observation of cores.

Open Access This article is distributed under the terms of the Creative Commons Attribution 4.0 International License (http://crea tivecommons.org/licenses/by/4.0/), which permits unrestricted use, distribution, and reproduction in any medium, provided you give appropriate credit to the original author(s) and the source, provide a link to the Creative Commons license, and indicate if changes were made.

\section{References}

Amy LA, Talling PJ, Peakall J, et al. Bed geometry used to test recognition criteria of turbidites and (sandy) debrites. Sed Geol. 2005;179(s 1-2):163-74. doi:10.1016/j.sedgeo.2005.04.007.

Bagnold RA. The flow of cohesionless grains in fluids. Philos Trans R Soc Math Phys Eng Sci. 1956;249(964):235-97. doi:10.1098/ rsta.1956.0020.

Bouma AH. Sedimentology of some Flysch deposits: a graphic approach to facies interpretation. Amsterdam: Elsevier Press; 1962. p. 1-5.

Deng XQ, Luo AX, Zhang ZY, et al. Geochronological comparison on Indosinian tectonic events between Qinling Orogeny and Ordos Basin. Acta Sedimentol Sin. 2013;31(6):939-53. doi:10. 14027/j.cnki.cjxb.2013.06.015 (in Chinese).

Ding XQ, Han MM, Zhang SN. The role of provenance in the diagenesis of siliciclastic reservoirs in the Upper Triassic Yanchang Formation, Ordos Basin, China. Pet Sci. 2013;10(2):149-60. doi:10.1007/s12182-013-0262-9.

Fu JH, Deng XQ, Chu MJ, et al. Features of deepwater lithofacies, Yanchang Formation in Ordos basin and its petroleum significance. Acta Sedimentol Sin. 2013;31(5):928-38. doi:10.14027/ j.cnki.cjxb.2013.05.011 (in Chinese).

Gao HC, Zheng RC, Wei Q, et al. Reviews on fluid properties and sedimentary characteristics of debris flows and turbidity currents. Adv Earth Sci. 2012;27(8):815-27. doi:10.11867/j.issn. 1001-8166.2012.08.0815 (in Chinese).

Hampton MA. Competence of fine-grained debris flows. J Sediment Res. 1975;45(4):834-44. doi:10.1306/212F6E5B-2B24-11D7$8648000102 \mathrm{C} 1865 \mathrm{D}$.

He ZX. The evaluation of the Ordos Basin and oil and gas. Bejing: Peking: Petroleum Industry Press; 2003. p. 88-105 (in Chinese).

Herrington PM, Pederstad K, Dickson JAD. Sedimentology and diagenesis of resedimented and rhythmically bedded chalks from the Eldfisk Field, North Sea central Graben. AAPG Bull. 1991;75(11):1661-74. doi:10.1306/0c9b29cf-1710-11d7$8645000102 \mathrm{c} 1865 \mathrm{~d}$.

Huneke H, Mulder T. Deep-sea sediments. London: Elsevier Press; 2011. p. 46-54. 
Kuenen PH, Migliorini CI. Turbidity currents as a cause of graded bedding. J Geol. 1950;58(2):91-127. doi:10.1086/625710.

Lei Y, Luo XR, Wang X, et al. Characteristics of silty laminae in Zhangjiatan shale of southeastern Ordos Basin, China: implications for shale gas formation. AAPG Bull. 2015;99(4):661-87. doi:10.1306/09301414059.

Li XB, Chen Q, Liu HQ, et al. Features of sandy debris flows of the Yanchang Formation in the Ordos basin and its oil and gas exploration significance. Acta Geologica Sinica (English edition). 2011a;85(5):1187-202. doi:10.1111/j.1755-6724.2011.00550.x.

Li XB, Fu JH, Chen QL, et al. The concept of sandy debris flow and its application in the Yanchang Formation deep water sedimentation of the Ordos basin. Adv Earth Sci. 2011b;26(3):286-94. doi:10.11867/j.issn.1001-8166.2011.03.0286 (in Chinese).

Li XB, Liu HQ, Zhang ZY, et al. Argillaceous parcel structure: a direct evidence of debris flow origin of deep-water massive sandstone of Yanchang Formation, Upper Triassic, the Ordos Basin. Acta Sedimantol Sinica. 2014;32(4):611-22. doi:10. 14027/j.cnki.cjxb.2014.04.005 (in Chinese).

Li XB, Zl Yang, Wang J, et al. Mud-coated intraclasts: a criterion for recognizing sandy mass-transport deposits-deep-lacustrine massive sandstone of the Upper Triassic Yanchang Formation, Ordos Basin, Central China. J Asian Earth Sci. 2016; doi:10.1016/j. jseaes.2016.06.007.

Li Y, Zheng RC, Zhu GJ, et al. Reviews on sediment gravity flow. Adv Earth Sci. 2011c;26(2):157-65. doi:10.11867/j.issn.10018166.2011.02.0157 (in Chinese).

Liu F, Zhu XM, Li Y, et al. Characteristics of the late Triassic deepwater slope break belt in southwestern Ordos Basin and its control on sandbodies. Geol J China Univ. 2015a;21(4):674-84. doi:10.16108/j.issn1006-7493.2015051 (in Chinese).

Liu F, Zhu XM, Li Y, et al. Sedimentary characteristics and facies model of gravity flow deposits of Late Triassic Yanchang Formation in southwestern Ordos Basin, NW China. Pet Explor Dev. 2015b;42(5):633-45. doi:10.1016/S1876-3804(15)30058-6.

Marr JG, Harff PA, Shanmugam G, et al. Experiments on subaqueous sandy gravity flows: the role of clay and water content in flow dynamics and depositional structures. GSA Bull. 2001;113(11): 1377-86. doi:10.1130/0016-7606(2001)113\%3C1377:EOSSGF\% 3E2.0.CO;2.

Mulder T, Alexander J. The physical character of subaqueous sedimentary density currents and their deposits. Sedimentology. 2001;48(2):269-99. doi:10.1046/j.1365-3091.2001.00360.x.

Mulder T, Syvitski JPM, Migeon S, et al. Marine hyperpycnal flows: initiation, behavior and related depositsA review. Mar Pet Geol. 2003;20(6-8):861-82. doi:10.1016/j.marpetgeo.2003.01.003.

$\mathrm{Pu}$ XG, Zhou LH, Han WZ, et al. Gravity flow sedimentation and tight oil exploration in lower first member of Shahejie Formation in slope area of Qikou Sag, Bohai Bay Basin. Pet Explor Dev. 2014;41(2):153-64. doi:10.1016/S1876-3804(14)60018-5.

Shanmugam G. High-density turbidity currents: are they sandy debris flows? J Sediment Res. 1996;66(1):2-10. doi:10.1306/ D426828E-2B26-11D7-8648000102C1865D.

Shanmugam G. 50 years of the turbidite paradigm (1950s-1990s): deep-water processes and facies models-a critical perspective. Mar Pet Geol. 2000;17(2):285-342. doi:10.1016/S0264-8172(99) 00011-2.

Shanmugam G. New perspectives on deep-water sandstones: origin, recognition, initiation, and reservoir quality. Oxford: Elsevier Press; 2012. p. 75-85.

Shanmugam G. New perspectives on deep-water sandstones: implications. Pet Explor Dev. 2013;40(3):316-24. doi:10.1016/b9780-444-56335-4.00009-6.

Shanmugam G. Submarine fans: a critical retrospective (1950-2015). J Palaeogeogr. 2016;5(2):110-84. doi:10.1016/j.jop.2015.08. 011.
Shanmugam G, Moiola RJ. Reinterpretation of depositional processes in a classic flysch sequence in the Pennsylvanian Jackfork Group, Ouachita Mountains: Reply. AAPG Bull. 1997;81: 476-91. doi:10.1306/522b43a7-1727-11d7-8645000102c1865d.

Talling PJ, Giuseppe M, Fabrizio F. Can liquefied debris flows deposit clean sand over large areas of sea floor? field evidence from the Marnoso-arenacea formation, Italian Apennines. Sedimentology. 2012a;60(3):720-62. doi:10.1111/j.1365-3091. 2012.01358.x.

Talling PJ, Masson DG, Sumner EJ, et al. Subaqueous sediment density flows: depositional processes and deposit types. Sedimentology. 2012b;59(7):1937-2003. doi:10.1111/j.1365-3091. 2012.01353.x

Tan MX, Zhu XM, Zhu SF. Research on sedimentary process and characteristics of hyperpycnal flows. Geol J China Univ. 2015;21(1):94-104. doi:10.16108/j.issn1006-7493.2014095 (in Chinese).

Xian BZ, Wan JF, Dong YL, et al. Sedimentary characteristics, origin and model of lacustrine deep-water massive sandstone: an example from Dongying Formation in Nanpu Depression. Acta Pet Sinica. 2013;29(9):3287-99 (In Chinese).

Yang H, Deng XQ. Deposition of Yanchang Formation deep-water sandstone under the control of tectonic events, Ordos Basin. Pet Explor Dev. 2013;40(5):549-57. doi:10.1016/S1876-3804(13) 60072-5.

Yang H, Fu JH, He HQ, et al. Formation and distribution of large lowpermeability lithologic oil regions in Huaqing, Ordos Basin. Pet Explor Dev. 2012;39(6):683-91. doi:10.1016/S1876-3804(12) 60093-7.

Yang RZ, He ZL, Qiu GQ, et al. Late Triassic gravity flow depositional systems in the southern Ordos Basin. Pet Explor Dev. 2014;41(6):724-33. doi:10.1016/S1876-3804(14)60086-0.

Yang T, Cao YC, Wang YZ, et al. Status and trends in research on deep-water gravity flow deposits (English edition). Acta Geol Sinica. 2015a;89(2):610-31. doi:10.1111/1755-6724.12451.

Yang T, Cao YC, Wang YZ, et al. Sediment dynamics process and sedimentary characteristics of hyperpycnal flows. Geol Rev. 2015b;61(1):23-33. doi:10.16509/j.georeview.2015.01.006 (in Chinese).

Yuan XJ, Lin SH, Liu Q, et al. Lacustrine fine-grained sedimentary features and organic rich shale distribution pattern: a case study of Chang 7 Member of Triassic Yanchang Formation in Ordos Basin, NW China. Pet Explor Dev. 2015;42(1):37-47. doi:10. 1016/S1876-3804(15)60004-0.

Zavala C. Ancient lacustrine hyperpycnites: a depositional model from a case study in the Rayoso Formation (Cretaceous) of West-Central Argentina. J Sedim Res. 2006;76(1-2):41-59. doi:10.2110/jsr.2006.12.

Zavala C, Arcuri M. Intrabasinal and extrabasinal turbidites: origin and distinctive characteristics. Sediment Geol. 2016;337:36-54. doi:10.1016/j.sedgeo.2016.03.008.

Zavala C, Marcano J, Carvajal J, et al. Genetic Indices in hyperpycnal systems: a case study in the late Oligocene-Early Miocene Merecure Formation, Maturin subbasin, Venezuela. Sediment transfer from shelf to deep water - revisiting the delivery system. Oklahoma: SEPM Press; 2011. p. 31-51.

Zhang $\mathrm{H}$, Peng PA, Zhang WZ. Zircon U-Pb ages and Hf isotope characterization and their geological significance of Chang 7 tuff of Yanchang Formation in Ordos Basin. Acta Pet Sinica. 2014;30(2):565-75 (in Chinese).

Zou CN, Wang L, Li Y, et al. Deep-lacustrine transformation of sandy debrites into turbidites, Upper Triassic, Central China. Sediment Geol. 2012;265-266:143-55. doi:10.1016/j.sedgeo.2012.04.004. 